\title{
ANALISIS KESULITAN SISWA SMP MENGHADAPI SOAL BERPIKIR KRITIS DAN KREATIF MATEMATIS
}

\author{
Indra Siregar', Darhim², Endang C M Asih ${ }^{3}$ \\ ${ }^{1}$ STKIP Sebelas April \\ dracakep@yahoo.co.id \\ ${ }^{2,3}$ Universitas Pendidikan Indonesia \\ darhim55@yahoo.com \\ endangcahya@upi.edu
}

\begin{abstract}
ABSTRAK
Kemampuan berpikir kritis dan kreatif merupakan hal yang penting dalam belajar matematika, namun upaya untuk meningkatkan kemampuan berpikir kritis dan kreatif di Indonesia belum berjalan dengan baik. Karena itu peneliti ingin mengkaji dimana letak permasalahan siswa dalam menghadapi soal-soal berpikir kritis dan kreatif matematis. Metode penelitian yang digunakan dalam penelitian ini adalah metode kualitatif dengan disain Basic qualitativa research approach. Kegiatannya adalah mengkaji jawaban siswa hasil mengerjakan soal berpikir kritis dan kreatif matematis siswa. Penelitian dilaksanakan di dua SMP di kabupaten Cianjur. Hasil penelitian menunjukkan bahwa permasalahan yang menyebabkan siswa lemah dalam menghadapi soal-soal berpikir kritis dan kreatif matematik adalah banyak siswa masih tidak dapat memahami masalah.
\end{abstract}

Kata Kunci: berpikir kritis matematis, berpikir kreatif matematis, analisis kesulitan siswa.

\begin{abstract}
Critical thinking and creative tihinking ability are the important thing on matemathical learning, but the effort to eancreasing its are not optimal yet. So that, we make the research to looking for what the problem of the student on confront mathematical critical and creative thinking task. The metod of the research is Basic qualitativa research approach. The activity is examine student's answer of the mathematical critical and creative tihinking task. The research was be done at two SMP in Kabupaten Cianjur. The result of the research show that the problem which make studens can not confront the mathematical critical and creative tihinking task is they still can not understanding the problem.
\end{abstract}

Keywords: mathematical critical thinking, mathematical creative thinking, student difficulty analysis.

\section{PENDAHULUAN}

Matematika merupakan mata pelajaran yang menjadi bagian dari kelompok mata pelajaran ilmu pengetahuan dan teknologi. Kelompok mata pelajaran ilmu pengetahuan dan teknologi memiliki peran untuk mengenal, menyikapi, mengapresiasi, menguasai, menerapkan dan mengembangkan ilmu pengetahuan dan teknologi serta memiliki kemampuan berpikir ilmiah secara kritis, kreatif dan mandiri (Mendiknas, 2006b). Oleh 
karena itu, matematika memiliki peran yang sama dengan kelompok mata pelajaran ilmu pengetahuan dan teknologi, yaitu untuk mengenal, menyikapi, mengapresiasi, menguasai, menerapkan dan mengembangkan ilmu pengetahuan dan teknologi serta memiliki kemampuan berpikir ilmiah secara kritis, kreatif, dan mandiri.

Berpikir kritis dan kreatif menjadi hal yang penting dalam belajar matematika sejak berpikir ilmiah secara kritis, kreatif, dan mandiri menjadi salah satu tujuan dalam belajar matematika. Pentingnya berpikir kritis dan kreatif dalam pembelajaran matematika dipertegas oleh pemerintah dengan menetapkan penguasaan kemampuan kritis, dan kreatif sebagai salah satu standar kelulusan matematika (Mendiknas, 2006a). Dengan demikian, siswa yang berhasil belajar matematika diharapkan memiliki kemampuan berpikir kritis, dan kreatif yang baik.

Upaya untuk meningkatkan kemampuan berpikir kritis dan kreatif belum berjalan dengan baik. Terlihat masih banyak siswa yang masih kesulitan dalam menghadapi soalsoal non-rutin (Mullis, Martin, \& Foy, 2012; OECD, 2014; Hutapea, 2013; Palinussa, 2012; Zulkarnain, 2013; Wahyuningrum, 2014; Pujiastuti, 2014). Oleh karena itu, peneliti ingin mengkaji dimana letak permasalahan siswa dalam menghadapi soal-soal non-rutin.

Penelitian ini merupakan tindak lanjut dari temuan pada penelitian sebelumnya yang sudah dipublikasikan pada jurnal Mosharafa terbitan 5 jilid 3. Salah satu temuan mengungkapkan bahwa banyak siswa bermasalah dalam menghadapi soal-soal nonrutin (Siregar, 2016).

\section{METODE PENELITIAN}

Metode penelitian yang digunakan dalam penelitian ini adalah metode kualitatif dengan disain Basic qualitativa research approach. Kegiatannya adalah mengkaji jawaban siswa hasil mengerjakan soal berpikir kritis dan kreatif matematis siswa. Kajian dilakukan tidak hanya berdasarkan sudut pandang peneliti, akan tetapi juga melihat dari sudut pandang beberapa pakar pendidikan matematika.

Soal berpikir kritis dan kreatif matematis yang digunakan dalam penelitian ini menggunakan materi matematika SMP dengan topik lingkaran. Materi ini dipilih karena dipandang menurut peneliti merupakan materi yang cukup mudah. Bobot kesulitan materi dipilih yang mudah untuk menghindari masalah munculnya argumentasi yang berisi bahwa ketidakmampuan siswa dalam menghadapi soal berpikir kritis dan kreatif dikarenakan sulitnya materi yang diberikan. Soal ini diambil dari Siregar (2012) dan dikembangkan lagi berdasarkan beberapa uji coba dan divalidasi oleh beberapa ahli. 
Penelitian ini merupakan bagian dari penelitian yang sudah dipublikasikan pada prosiding seminar internasional Journal of Physics: Conferences series 812(1). Soal dikerjakan berpikir kritis dan kreatif dikerjakan setelah kegiatan pembeajaran mateatika dalam penelitian tersebut. Dalam penelitian tersebut diungkapkan bahwa siswa memiliki kerpercayaan diri yang bagus (Siregar, Darhim \& Asih, 2017). Artinya dapat dipastikan siswa mengerjakan soal berpikir kritis dan kreatif setelah mendapatkan materi serta dalam keadaan memiliki kepercayaan diri yang baik.

Penelitian dilaksanakan di dua SMP Negeri di kabupaten Cianjur. Sekolah yang dipilih merupakan sekolah yang jauh dari jangkauan lembaga bimbingan belajar sehingga diharapkan dapat mencerminkan pendidikan yang diselenggarakan oleh pemerintah. Dipastikan juga bahwa sekolah yang dipilih merupakan sekolah yang jauh dari keramaian kota sehingga dapat dipastikan anak-anak yang bersekolah masih belum terkontaminasi oleh pergaulan bebas, kenakalan remaja, serta hal-hal yang berbau narkoba. Sehingga jika ada permasalahan yang muncul pada siswa dalam belajar diharapkan penyebab permasalahan tersebut tidak berasal dari hal-hal diluar aktifitas pembelajaran diluar kelas.

\section{HASIL DAN PEMBAHASAN}

Analisis kesulitan siswa terlihat dari kesalahan siswa dalam menjawab butir soal kemampuan berpikir kritis dan berpikir kreatif yang menjadi alat ukur dalam penelitian ini. Butir soal nomor 1, 2, dan 3 merupakan soal kemampuan berpikir kritis, sedangkan butir soal nomor 3 dan 4 merupakan soal kemampuan berpikir kreatif. Berikut analisis kesulitan dari kesalahan siswa dalam menjawab yang paling banyak terjadi.

\section{Soal Nomor 1}

Ada dua buah gir motor. Jarak kedua pusat gir $15 \mathrm{~cm}$, dan masing-masing gir memiliki diameter $10 \mathrm{~cm}$. Sebuah rantai yang panjangnya $30 \mathrm{~cm}$ akan dipasang pada kedua gir seperti pada gambar dibawah. Apakah panjang rantai cukup untuk dipasang pada kedua gir? Jelaskan alasannya!

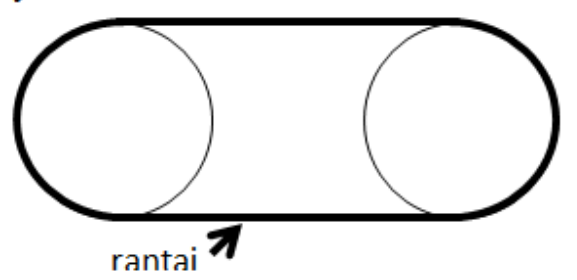

Gambar 1. Soal Nomor 1

Siswa diperintahkan untuk memeriksa apakah rantai cukup berdasarkan informasi yang diberikan. Jawaban siswa akan beragam, namun siswa yang kemampuan berpikir kritisnya baik hanya akan menggunakan informasi yang relevan (cocok untuk mengukur 
indikator menentukan informasi relevan dan tidak relevan) dan cukup (cocok untuk mengukur indikator menentukan informasi yang diberikan) untuk menunjukan bahwa rantai tidak cukup. Jika informasi yang di ambil berlebihan, maka siswa kurang kritis.

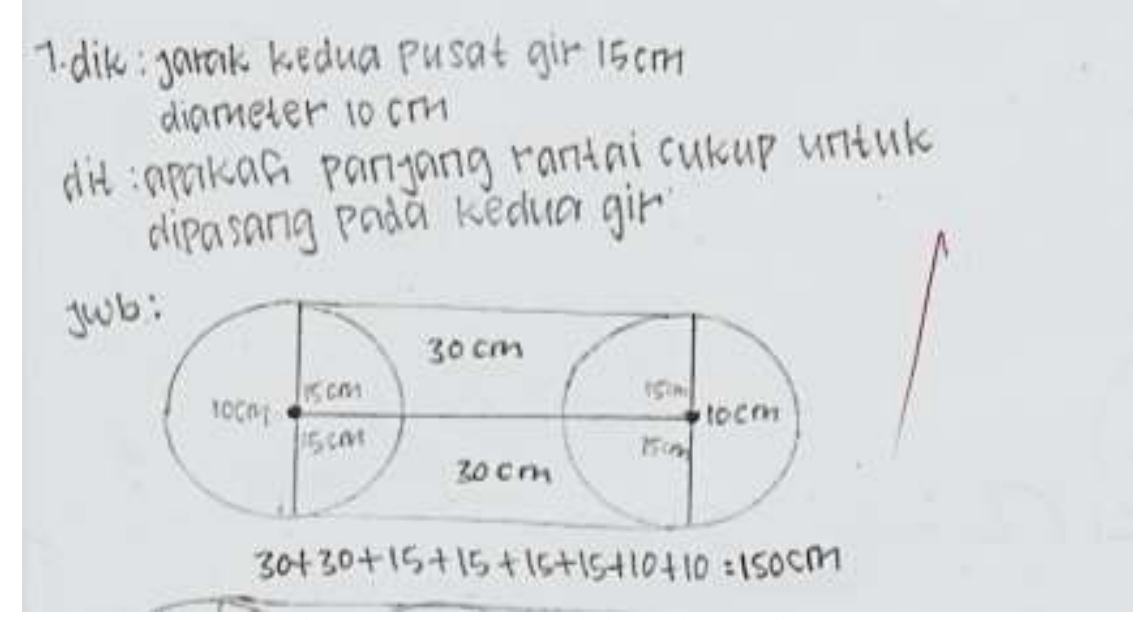

Gambar 2. Jawaban Salah pada Soal Nomor 1

Contoh kasus jawaban salah yang sering muncul dari soal nomor 1 dapat dillihat pada Gambar 2. Terlihat dalam Gambar 2, banyak angka-angka yang kurang tepat, seperti jarak antara pusat kedua gear yang seharusnya $15 \mathrm{~cm}$, ditulis $30 \mathrm{~cm}$. Bahkan panjang jarijari yang seharusnya $10 \mathrm{~cm}$, ditulis $15 \mathrm{~cm}$ dan diameter lingkarannya adalah $10 \mathrm{~cm}$. Artinya siswa belum bisa menentukan informasi yang relevan.

Gambar 2 juga menunjukkan bahwa siswa tidak hanya belum bisa menentukan informasi yang relevan, tetapi juga belum bisa menentukan informasi yang dibutuhkan. Terlihat terlalu banyak angka yang tidak diperlukan tercantum dan melakukan perhitungan yang tidak jelas dasar dan arahnya. Menjawab soal nomor 1 sebetulnya sederhana. cukup dengan melihat jarak kedua pusat gir dan membandingkan dengan panjang rantai yang tesedia, sudah dapat menetukan apakah rantai cukup atau tidak.

\section{Soal Nomor 2}

Perhatikan gambar lingkaran-lingkaran yang dililit sesuai pola-pola seperti pada gambar berikut (seperti drum yang dililit tali, yang dilihat dari atas):

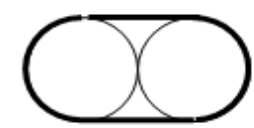

Pola 1

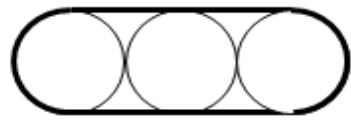

Pola 2

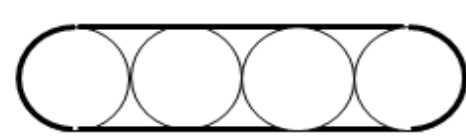

Pola 3

Pola keempat dan pola seterusnya memiliki bentuk yang mirip.

Jika jari-jari seluruh lingkaran di tiap pola adalah $7 \mathrm{~cm}$, menurut kamu berapa panjang lilitan minimal untuk polake 4 dan ke 6 ?

Gambar 3. Soal Nomor 2

Siswa diperintahkan untuk memperhatikan pola-pola yang diberikan. Pola-pola ini dijadikan acuan untuk memecahkan soal yang sesungguhnya, yaitu mencari panjang lilitan 
minimal untuk pola ke 4 dan ke 6. Jika siswa kritis, maka siswa akan menentukan pola ke 4 dan ke enam sama dengan pola sebelumnya. Jika terpikir yang lain, maka siswa kurang kritis. Soal ini cocok untuk mengukur kemampuan berpikir kritis tentang menentukan dan menyimpulkan sub tujuan yang mengarah ke tujuan.

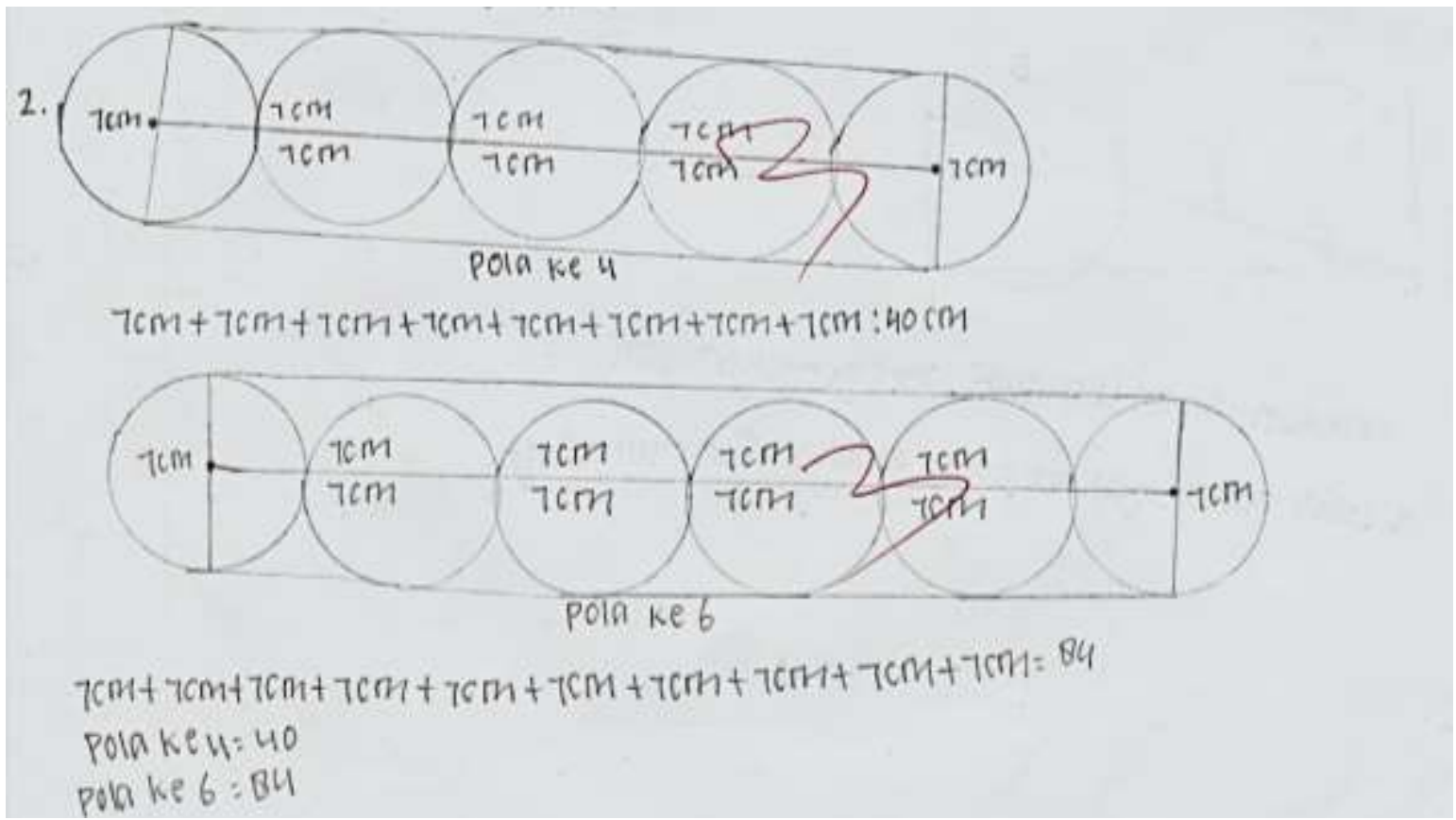

Gambar 4. Jawaban Salah pada Soal Nomor 2

Contoh jawaban salah nomor 2, terlihat siswa dapat menentukan pola keempat dan pola ke enam dari gambar pada soal, namun dalam menghitung untuk mecari jawaban yang benar masih tidak sesuai dengan konsep menghitung panjang lilitan dalam materi garis singgung lingkaran. Telihat pada Gambar 4. penempatan panjang jari-jari tidak tepat, sehingga menghasilkan jumlah yang keliru.

\section{Soal Nomor 3}

Dua belas buah koin disusun dalam sebuah bidang ABCDEFGHJKL seperti pada gambar di bawah. Koin-koin dalam bidang tersebut berukuran sama dan memiliki jari-jari $5 \mathrm{~cm}$.

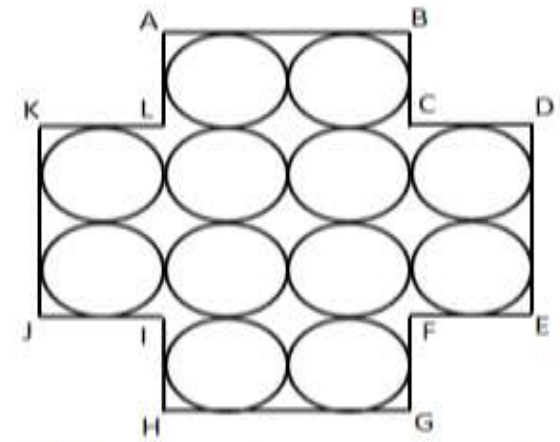

a. Menurut kamu bagiamana cara menghitung luas bidang ABCDEFGHIJL dan berapa luasnya?

b. Adakah cara lain menghitung luas bidang tersebut? Tuliskan caranya!

Gambar 5. Soal Nomor 3 
Soal nomor 3a. berisi perintah kepada siswa untuk mencari luas bidang bukan lingkaran dengan bantuan informasi lingkaran. Untuk dapat menjawab soal siswa harus merinci masalah dan mengembangkan gagasan (cocok untuk mengukur kemampuan berpikir kreatif dengan aspek elaborasi). Dalam merinci masalah dan mengembangkan gagasan, tentu siswa mengingat kembali masalah-masalah lain yang pernah dikerjakan sebelumnya (cocok untuk mengukur kemampuan berpikir kritis dengan indikator menentukan persamaan dan perbedaan antara masalah yang diberikan dan masalah lainnya). Setelah itu siswa harus menentukan cara menyelesaikan masalah (cocok untuk mengukur kemampuan berpikir kritis dengan indikator memilih dan membenarkan strategi untuk memecahkan masalah). Siswa dikatakan memiliki kemampuan berpikir kritis dan kreatif yang baik jika siswa mampu mengembangkan konsep lingkaran ke konsep persegi panjang. Kemampuan kritis dan kreatif siswa buruk jika siswa mencari luas bidang dengan cara mnejumlahkan semua luas lingkaran dengan luas di sela-sela lingkaran dalam bidang ABCD.EFGH.IJKL.

Soal nomor 3b. memiliki banyak cara dalam menyelesaikannya, siswa diminta untuk mengutarakan cara lain yang mungkin terpikir. Cocok untuk mengukur aspek flexibility pada berpikir kreatif dan mengukur indikator menunjukkan metode alternatif untuk memecahkan masalah pada berpikir kreatif serta indikator menentukan persamaan dan perbedaan antara masalah yang diberikan dan masalah lainnya pada hakikatnya ada pada tiap soal, namun dikhususkan pada soal No. 3 karena masalah soal nomor tiga tersebut lebih kompleks.

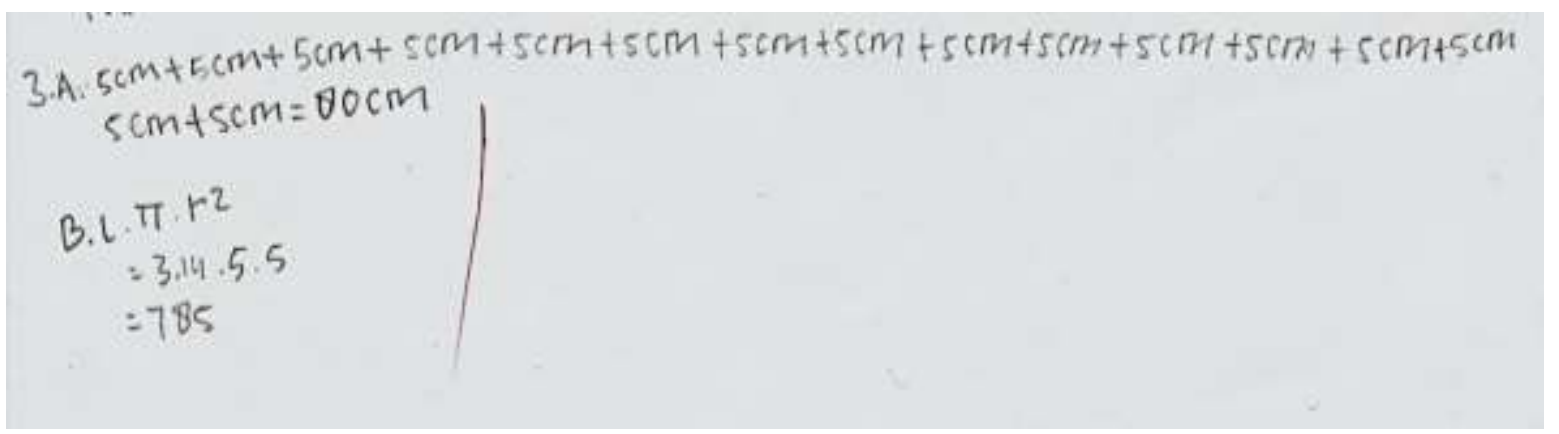

Gambar 6. Jawaban Salah pada Nomor 3

Pada Gambar 6. terlihat kekeliruan yang cukup parah. Menjumlahkan jari-jari begitu saja tanpa memperhatikan bentuk gambar pada soal. Konsep garis singgung yang mendasari konsep soal nomor 3 ini tidak digunakan sama sekali. 


\section{Soal Nomor 4}

Perhatikan petunjuk berikut.

- Ada dua buah lingkaran yaitu lingkaran A dan B.

- Lingkaran A memiliki satu buah garis singgung yaitu garis $k$

- Lingkaran B juga memiliki satu buah garis singgung yaitu garis $l$

- Garis $k$ dan garis $l$ berpotongan dan membentuk sudut siku-siku/sudut $90^{\circ}$

a. Buatlah gambar berdasarkan petunjuk di atas!

b. Adakah bentuk gambar lain yang berbeda? Jika ada, gambarkan dua buah bentuk gambar yang berbeda!

\section{Gambar 7. Soal Nomor 4}

Pada soal nomor 4a., siswa diperintahkan untuk membuat gambar yang memiliki kemungkinan gambar yang tak terhingga banyaknya, sehingga siswa dapat membuat gambar yang mungkin berbeda antara satu dan lainnya. Gambar yang dibuat benar-benar asli hasil pemikiran siswa sendiri. Cocok untuk mengukur kemampuan berpikir kreatif dengan aspek original.

Pengalaman yang diperoleh dari nomer $4 \mathrm{a}$, siswa sudah mengetahui bentuk gambar yang diinginkan dari soal. Dari pengalaman tersebut, pada soal nomor 4b. siswa diperintahkan untuk membuat gambar-gambar yang berbeda dengan kriteria lebih khusus. Cocok untuk mengukur kemampuan berpikir kreatif dengan aspek fluency.

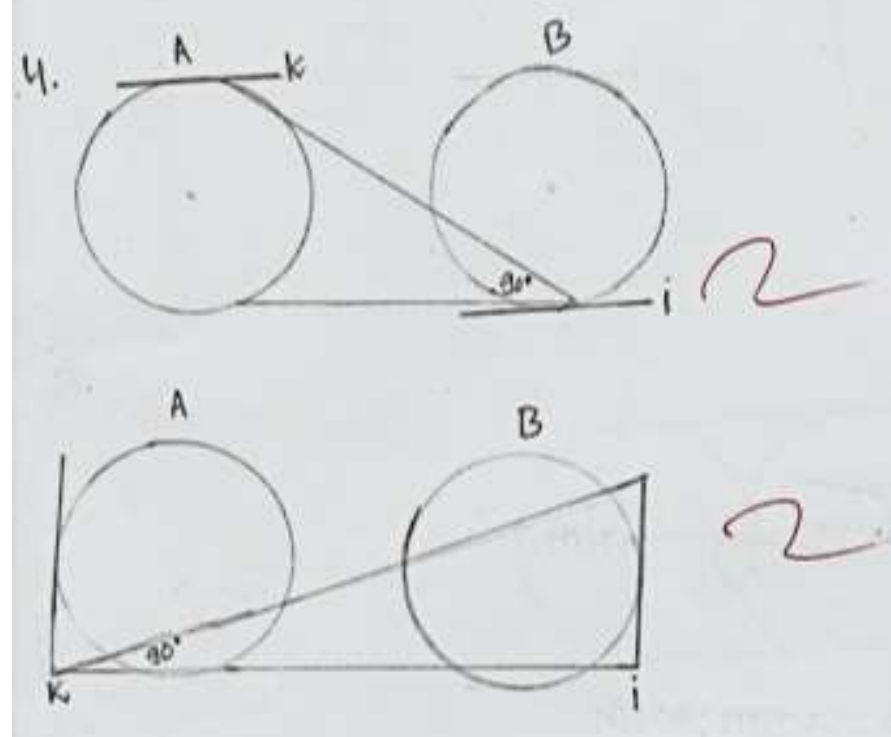

Gambar 8. Jawaban Salah pada Nomor 4

Pada Gambar 8 terlihat siswa sudah bisa memahami bahwa lingkaran yang diperlukan ada dua, namun siswa belum bisa memaknai dua garis singgung lingkaran yang berpotongan saling tegak lurus. Siswa masih belum bisa memahami maksud dari soal. Keempat soal di atas merupakan soal berpikir kritis dan kreatif matematis, namun dalam penyelesaiannya tidak akan pernal lepas dari tahapan cara menyelesaikan masalah. 
$\overline{\text { Menurut Polya (1957) cara memecahkan masalah terbagi atas empat fase. Fase pertama }}$ adalah memahami masalah. Fase kedua merencanakan rencana penyelesaian. Fase ke tiga adalah melaksanakan rencana. Fase keempat adalah memeriksa kembali hasil pekerjaan. Jika kita perhatikan kajian per butir soal, permasalah terjadi pada fase pertama dan kedua.

Pada jawaban dari soal nomor satu terlihat siswa mencantumkan banyak angka tetapi tidak menyinggung masalah utamanya, yaitu apakah rantai cukup atau tidak. Jelas, bahwa dalam soal nomor satu siswa tidak dapat memahami masalah sehingga penyelesaian yang dilakukan tidak terarah.

Pada jawaban soal nomor dua, siswa sudah bisa menentukan pola yang diminta, namun tidak dapat melakukan perhitungan dengan tepat. Siswa tidak dapat menggunakan konsep dengan benar. Artinya siswa bermasalah pada fase dua dalam menghadapi masalah menurut polya. Jawaban soal nomor tiga a dan $b$, serta empat a dan b terlihat siswa tidak menjawab sesuai dengan masalah yang ditanyakan. Sehingga langkah penyelesaian yang dilakukan tidak jelas arahnya.

\section{Analisi Menurut Ahli Pendidikan Matematika Pertama}

\section{Analisa Jawaban Soal Nomor 1}

Jawaban siswa pada soal nomor 1, kurang tepat karena siswa salah persepsi tenang apa yang diketahui pada soal sehingga menghasilkan jawaban yang salah. Kesalahan persepsi yakni saat menerapkan panjang atau jarak kedua pusat gir $15 \mathrm{~cm}$ dan perkiraan rantai yang ada pada gir, selain itu tidak ada penjelasan alasan dari jawaban yang diutarakan.

\section{Analisa Jawaban Soal Nomor 2}

Jawaban siswa pada soal nomor 2 kurang tepat karena siswa salah memahami jarijari lingkaran yang diketahui pada soal dan lilitan tali yang ada pada gambar di soal kurang diperhatikan siswa sehingga siswa hanya menghitung panjang tali yang ada di bagian atas dan bawah lingkaran, sedangkan lilitan tali yang ada pada lengkung lingkaran tidak diperhatikan sehingga menhasilkan panjang lilitan yang salah.

\section{Analisa Jawaban Soal Nomor 3}

Jawaban siswa pada soal nor 3.a kurang tepat karena siswa fokus pada jari-jari yang diketahui pada soal dan tidak memahami pertanyaan yang dimaksud.

Jawaban siswa pada soal 3.b. masih kurang tepat karena jawaban siswa seharusnya memperhatikan cara yang berbeda untuk menghitung luas bidang tetapi siswa menjawab 
dengan cara luas lingkaran yang menghasilkan luas lingkaran pula, bukanluas bidang yang dimaksud. Hal tersebut menunjukkan siswa kurangmemahami soal yang diberikan.

\section{Analisa Jawaban Soal Nomor 4}

Jawaban siswa pada soal nomor 4.a menunjukka gambaran tentang dua lingkaran yang mempunyai dua garis singgung yang saling tegak lurus tetapi siswa salah memahami garis singgung yang dimaksud, karena siswa menggambarkan garis tersebut dengan posisi $90^{\circ}$ yang tidak seharusnya yakni kurang dari $90^{\circ}$.

Jawaban siswa pada soal nomor 4.b siswa diminta untuk menggambarkan dalam bentuk lain dari jawaban no 4.a. jawaban siswa tersebut juga masih kurang tepat.

\section{Analisi Menurut Ahli Pendidikan Matematika Kedua}

\section{Analisa Jawaban Soal Nomor 1}

Siswa masih salah menempatkan ukurannya, dari soal sudah jelas jarak antar titik pusatnya saja $15 \mathrm{~cm}$, atas dan bawah sudah $30 \mathrm{~cm}$, jadi sudah jelas rantai sepanjang $30 \mathrm{~cm}$ tidak cukup. Siswa belum paham apa yang diinginkan soal

\section{Analisa Jawaban Soal Nomor 2}

Siswa terlihat belum mahami materi panjang lilitan. Konsep dasar keliling lingkaran serta operasi penjumlahan dan pengurangan masih bermasalah.

\section{Analisa jawaban soal nomor 3}

Siswa belum memahami apa yang diinginkan soal, selain itu siswa juga masih belum memahami perbedaan konsep luas dan keliling.

\section{Analisa Jawaban Soal Nomor 4}

Terlihat siswa sudah memahami dalam menggambar dua lingkaran, tetapi untuk berpikir tentang menggambar garis tegak lurusnya belumm bisa.

Empat analisa jawaban soal menunjukkan bahwa permasalahan terbanyak adalah tidak dapat menganalisis masalah. Tentu jika tidak dapat menganalisis masalah, jangankan untuk menghadapi soal berpikir kritis dan kreatif, untuk menghadapi masalah biasa pun masih sulit.

\section{KESIMPULAN}

Kajian hasil penelitian menunjukkan bahwa salah satu permasalahan yang dialami siswa dalam menghadapi soal berpikir kritis dan kreatif matematis adalah masih lemahnya 
siswa dalam memahami masalah. Permasalahan ini tentu menjadi penghambat yang sangat mendasar, karena ketidakmampuan memahami masalah dalam menghadapi soal dapat membuat siswa tidak dapat merancang strategi penyelesaian masalah yang tepat serta menyelesaikan masalah yang ada di dalam soal. Jangankan untuk soal yang menuntut berpikir tingkat tinggi, soal biasa puan akan sulit dihadapi oleh siswa.

\section{REKOMENDASI}

Hasil penelitian dalam kajian ini memunculkan temuan yang jika tidak ditangani secara serius maka akan menyulitkan perkembangan kemampuan berpikir kritis dan kreatif siswa. Perlu upaya penanganan dan penelitian yang lebih lanjut untuk menanggulangi permasalahan yang muncul dari penelitian ini. Akan ada kajian lebih mendalam lagi terkait hasil penelitian ini untuk mengunggkap kemungkinan adanya faktor lain yang menyebabkan siswa-siswa mengalami permasalahan seperti ini. Diharapkan bantuan dari peneliti lain untuk menguji kemampuan berpikir kritis dan kreatif siswa SMP dengan soal yang sama dalam penelitian ini untuk mengungkap fenomena di daerah lain.

\section{UCAPAN TERIMAKASIH}

Saya ucapkan terima kasih kepada kepala sekolah SMP yang menjadi tempat penelitian, guru-guru serta siswa-siswa yang telah membantu dalam proses pelaksanaan penelitian ini. Subjek penelitian dalam penelitian ini sengaja disembunyikan untuk menjaga nama baik mereka, karena hal yang di kaji dalam penelitian ini merupakan hal yang bisa dianggap aib bagi sekolah, guru, serta siswa.

Saya ucapkan terimakasih pula pada Veny Triyana Andika Sari, M.Pd. dosen di jurusan Pendidikan Matematika IKIP Siliwangi dan Galih Isya Adani, S.Pd. ketua MGMP Matematika SMK Kabupaten Cianjur atas bantuan dalam memberikan analisa jawaban siswa.

\section{REFERENSI}

Hutapea, N. M. (2013). Peningkatan kemampuan penalaran, komunikasi matematis dan kemandirian belajar siswa SMA melalui pembelajaran generatif. UPI.

Mendiknas. (2006a). Peraturan Menteri pendidikan nasional Republik Indonesia Nomor 22 tahun 2006 Tentang Standar isi Untuk satuan pendidikan dasar dan menengah. Kementrian Pendidikan Nasional. Jakarta.

Mendiknas. (2006b). Peraturan Menteri pendidikan nasional Republik Indonesia Nomor 22 tahun 2006 Tentang Standar isi Untuk satuan pendidikan dasar dan menengah. Kementrian Pendidikan Nasional (Vol. 91). Jakarta. 
Mullis, I. V. S., Martin, M. O., \& Foy, P. (2012). Timss 2011 International Results in Mathematics. Netherland: International Association for the Evaluation of Educational Achievement (IEA).

OECD. (2014). PISA 2012 Results in Focus. PISA 2012 Result in Focus What 15-YearOlds Know and What They Can Do with What They Know, 1-44. https://doi.org/10.1787/9789264208070-en

Palinussa, A. L. (2012). Peningkatan Kemampuan Berpikir Kritis dan Kreatif Matematis serta Karakter Siswa dalam Pembelajaran Matematika Realistik Berbasis Budaya. UPI.

Polya, G. (1957). How To Solve It, A New Aspect of Mathematical Method (Second Edi). New Jersey: Princeton University Press.

Pujiastuti, H. (2014). Pembelajaran inquiri co-operation model untuk meningkatkan kemampuan pemecahan masalah, komunikasi, dan self-esteem matematis siswa SMP. UPI.

Siregar, I.; Darhim; Asih, E. C. M. (2017). Increasing Self-Confidence of Indonesian Low Ability Student with Green's Motivational Strategies. Journal of Physics: Conference Series, 812(1), 012104. Retrieved from http://iopscience.iop.org/article/10.1088/17426596/812/1/012104/pdf

Siregar, I. (2012). Menerapkan Pembelajaran Matematika dengan Pendekatan ModelEliciting Activities untuk Meningkatkan Kemampuan Berpikir Kreatif Matematis dan Self-Confidence Siswa SMP. UPI.

Siregar, I. (2016). Masalah Pembelajaran Pembuktian Matematika Bagi Mahasiswa di Indonesia. Mosharafa, 5(September 2016), 315-324. Retrieved from file:///D:/Documents/Documents/data2 lady/ALILA/226670-masalah-pembelajaranpembuktian-matemati-5a13ce7a.pdf

Wahyuningrum, E. (2014). Kemampuan pemecahan masalah, komunikasi dan disposisi matematika siswa SMP melalui strategi MEAs. UPI.

Zulkarnain, I. (2013). Kemampuan pemahaman dan komunikasi matematis siswa dalam pembelajaran kooperatif berbasis konflik kognitif. UPI. 